\title{
Falls in Unilateral Lower Limb Amputees Living in the Community: A Portuguese Study
}

\section{Queda na Comunidade em Amputados Unilaterais do Membro Inferior: Um Estudo Português}

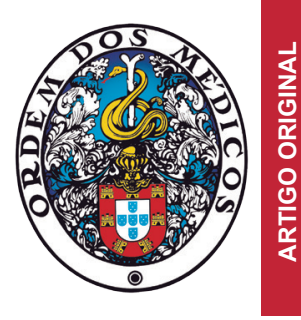

\author{
Gonçalo ENGENHEIROه ${ }^{1}$, João PINHEIRO ${ }^{2,3}$, Joana Santos COSTA ${ }^{2,3}$, Amílcar CORDEIRO ${ }^{2,3}$, Susana RAMOS ${ }^{6}$, \\ Pedro PEREIRA 2,4
}

Acta Med Port 2020 Oct;33(10):675-679 • https://doi.org/10.20344/amp.12615

\section{ABSTRACT}

Introduction: Lower limb amputees present a high risk of falling. This study aims to characterise fall history in unilateral lower limb amputees that are autonomous in the community, identifying differences between transfemoral and transtibial amputees and assessing fear of falling between fallers and non-fallers.

Material and Methods: Descriptive, cross-sectional study of consecutive community-dwelling unilateral lower limb adult amputees of any aetiology, attending outpatient consultation in a Portuguese Physical and Rehabilitation Medicine central and university hospital department. Inclusion criteria: a prior 12 week individualised rehabilitation program for prosthesis training; regular prosthesis use for more than one year with autonomous gait; and a Functional Independence Measure ${ }^{\circledR}$ score equal to or greater than 100 . Injury severity was classified according to the National Database of Nursing Quality Indicators ${ }^{\circledR}$ injury falls measure. In order to assess walking performance over short distances and fear of falling we used the 10-meter walk test and the Falls Efficacy Scale, respectively.

Results: In a sample of 52 lower limb amputees, mainly men (80.8\%) and of traumatic aetiology (63.5\%), with a mean age of $57.21 \pm$ 11.55 years, $36.5 \%$ reported at least one fall in the previous 12 months, all classified as minor injuries. Transfemoral amputees $(n=23)$ presented a higher number of falls $(2.22 \pm 3.23, p=0.025)$ and lower gait velocity $(0.77 \pm 0.26 \mathrm{~m}$ per second, $p<0.001)$. Regarding fear of falling, we found no significant differences between fallers and non-fallers.

Discussion: The prevalence of falls was low and of minor severity. Transfemoral amputees fell more often and were slower. There were no reported differences in fear of falling between groups.

Conclusion: This paper contributes information about Portuguese lower limb amputees, whose studies are scarce and are rarely dedicated to falling.

Keywords: Accidental Falls; Amputation/rehabilitation; Amputees/rehabilitation; Lower Extremity

\section{RESUMO}

Introdução: Amputados do membro inferior apresentam um elevado risco de queda. Neste estudo pretende-se caracterizar a história de queda em amputados unilaterais de membros inferiores, autónomos da comunidade, identificar diferenças entre transfemorais e transtibiais e avaliar diferenças no medo de cair entre os que caíram e os que não caíram.

Material e Métodos: Estudo descritivo, transversal, de amputados unilaterais de membros inferiores, adultos, residentes na comunidade, de qualquer etiologia, consecutivamente recrutados da consulta do serviço de Medicina Física e de Reabilitação de um hospital central e universitário de Portugal. Critérios de inclusão: reabilitação de 12 semanas para treino protético; uso regular de prótese superior a um ano, marcha autónoma e Medida de Independência Funcional ${ }^{\circledR}$ igual ou superior a 100. A gravidade de queda foi classificada recorrendo à National Database of Nursing Quality Indicators ${ }^{\circledR}$ injury falls measure e a capacidade de andar e medo de cair com, respetivamente, o 10-meter walk test e a Falls Efficacy Scale.

Resultados: Foi analisado um total de 52 amputados, maioritariamente homens (80,8\%) e de etiologia traumática (63,5\%) e com idade média $57,21 \pm 11,55$ anos, dos quais $36,5 \%$ relataram pelo menos uma queda, todas de baixa gravidade. Os transfemorais ( $n$ $=23$ ) apresentaram mais quedas $(2,22 \pm 3,23, p=0,025)$ e menor velocidade de marcha $(0,77 \pm 0,26 \mathrm{~m}$ por segundo, $p<0,001)$. Relativamente ao medo de cair, não encontrámos diferenças significativas entre doentes amputados com e sem história de quedas. Discussão: A prevalência e gravidade de queda foi baixa. Amputados transfemorais apresentaram mais quedas e menor velocidade de marcha. Não existiram diferenças no medo de cair em função da história de queda.

Conclusão: Este trabalho acrescenta informação acerca dos amputados do membro inferior portugueses, cujos estudos são escassos e raramente dedicados a queda.

Palavras-chave: Amputação/reabilitação; Amputados/reabilitação; Extremidade Inferior; Quedas Acidentais

\section{INTRODUCTION}

Lower limb amputation is a disabling clinical condition usually related to restriction in social participation. ${ }^{1,2}$ This is a highly prevalent condition and it is estimated that the number of people living with lower limb amputation may double in the next three decades. ${ }^{3}$ An English study estimates the prevalence rate of amputations to be $26.3 / 100000,{ }^{4}$ for

those aged of $50-84$ years old. In Portugal, national data on lower limb amputation is yet to be published.

Falls represent a significant health risk and are usually related to having less mobility, loss of balance, loss of confidence and self-imposed restriction on participation. 5,6 It is estimated that up to $30 \%$ of older people living in the

1. Serviço de Medicina Física e de Reabilitação. Centro Hospitalar de Entre o Douro e Vouga. Santa Maria da Feira. Portugal.

2. Departamento de Medicina Física e de Reabilitação. Centro Hospitalar e Universitário de Coimbra. Coimbra. Portugal.

3. Departamento de Medicina Física e de Reabilitação. Faculdade de Medicina. Universidade de Coimbra. Coimbra. Portugal.

4. Faculdade de Ciências do Desporto e Educação Física. Universidade de Coimbra. Coimbra. Portugal.

$\square$ Autor correspondente: Gonçalo Engenheiro. goncalo.engenheiro@gmail.com

Recebido: 29 de julho de 2019 - Aceite: 11 de dezembro de 2019 | Copyright $\odot$ Ordem dos Médicos 2020 
community will fall every year. ${ }^{7}$ Unilateral lower limb amputees are more prone to falling when compared to ablebodied individuals, with a reported incidence of $52.4 \%$ to $58 \%{ }^{8}$ among community-dwelling amputees. ${ }^{9}$ According to one study, $12 \%$ of falls were related to prosthetic conditions, $22 \%$ to the environment, and $48 \%$ were due to a combination of various intrinsic factors. ${ }^{8}$ Severe falls occur in 26.8 $\%^{10}$ to $40.4 \%{ }^{5}$ of the community-dwelling adult lower limb amputee population. ${ }^{9}$ The fall risk seems to be present from the moment of amputation until several years after the prosthetisation, probably due to progressive deterioration of balance. 9,11,12 Transfemoral amputation, lumbar and joint pain and several problems with stump or prosthesis were associated with an increased fall risk among lower limb amputees. 5,6

The ability to walk and perform independent activities of daily living (ADL) while wearing a prosthesis is usually associated with a better function. Conversely, fear of falls and deterioration of functionality can be strongly disabling. . $^{6,13,14}$ The Falls Efficacy Scale (FES) and the 10-meter walk test (10MWT) are two instruments used to characterise the functionality of lower limb amputees. ${ }^{15-17}$ FES measures fear of falls and 10MWT assesses walking speed over short distances. The level of functional performance is relevant to detect fall risk. Early identification ${ }^{8,9,19}$ and the ability to promote a rehabilitation program can decrease the number and lower the severity of falls in this population. ${ }^{20-22}$

The aims of this study were to characterize the fall history of Portuguese community-dwelling unilateral lower limb amputees with autonomous gait, to identify the main clinical differences between transfemoral and transtibial amputees and to assess the fear of falls between fallers and non-fallers.

\section{MATERIAL AND METHODS}

A descriptive and cross-sectional study was carried out by recruiting consecutive community-dwelling unilateral lower limb amputees, of any etiology, attending the amputee outpatient consultation of the Physical and Rehabilitation Medicine (PRM) department of Centro Hospitalar e Universitário de Coimbra (CHUC), Portugal, between October and December 2017.

The inclusion criteria were: age over 18 ; a prior 12 week individualised rehabilitation program for prosthesis training; regular prosthesis use (over eight hours daily) for more than one year with autonomous gait (with or without assistive technologies); and a Functional Independence Measure ${ }^{\circledR}$ $\left(\mathrm{FIM}^{\circledR}\right)$ score equal to or greater than 100.

The exclusion criteria were: various comorbidities (uncontrolled cardiovascular disorders, neurological, and vestibular or visual disorders), inability to fill in questionnaires; cognitive deterioration; inability to understand the Portuguese language.

The 12-week rehabilitation program focused on muscle strengthening, balance and gait kinematics training, assistive devices usage, and on promoting aerobic conditioning in ADL. It was designed by an experienced PRM medical team and implemented by qualified physiotherapists and rehabilitation nurses at the department of PRM.

Ethics committee approval was granted by the Ethics Committee of CHUC and written informed consent was obtained from each participant.

\section{Measures}

Every eligible patient replied to a questionnaire that included demographic (age and gender), clinical (amputation level, amputation etiology, years of prosthetisation and assistive walking device usage) and falls (number and severity of falls in the previous year) related questions.

FIM $^{\circledR}$ assesses 18 basic ADL divided into 6 main areas: self-care, sphincter control, transfers and locomotion; communication and social cognition. Each task is ranked on a 7-point ordinal scale ranging from 1 ('total assistance') to 7 ('complete independence') resulting in a total score of 18 - 126 points. ${ }^{23,24}$ We used FIM $^{\circledR}$ as an inclusion criterion to guarantee that only the amputees with high ADL independence were selected, thus ensuring a more homogenous sample concerning functionality. To the best of our knowledge, since the existing literature lacks any cut-off that indicates significantly greater independence regarding amputee patients, in this study it was defined as a minimum of 100 points to ensure that, on average, any eligible subject scored between 5 ('supervision or setup') and 6 ('modified independence').

In order to assess walking speed, we performed the $10 \mathrm{MWT},{ }^{15,17}$ which is a simple method of measuring walking speed in meters per second over a short duration. Subjects were instructed to walk a $10 \mathrm{~m}$ straight path distance at their preferred walking pace. Speed was calculated over the middle $6 \mathrm{~m}$ to allow for acceleration and deceleration at either end. We conducted three repetitions to calculate the average speed of each amputee. Participants who usually used walking aids (cane, crutches, or walker) performed the test with them.

In order to measure fear of falling we applied FES, ${ }^{16,18,25}$ which is based on the definition of fear as "a low perceived self-efficacy at avoiding falls during essential, non-hazardous activities of daily living". Self-efficacy is the personal judgment of an individual's capabilities within a particular domain of activities. Efficacy may be linked to functional decline since people with low perceived efficacy in an activity tend to avoid the activity. ${ }^{25,26}$ Thus, higher fall self-efficacy indicates less fear of falling. FES is composed of 10 items corresponding to tasks of various degrees of difficulty; the total score ranges from 10 to 100 with higher scores indicating less fear of falling. ${ }^{18}$

We classified fall-related injury severity according to the National Database of Nursing Quality Indicators ${ }^{\circledR}$ (NDNQI ${ }^{\circledR}$ ) Injury Falls Measure (none, minor, moderate, major, or death). ${ }^{27}$

All variables were compiled for descriptive analysis. Frequency tables, measures of central tendency (mean, median), and dispersion measures (standard deviation) were used. Normality of distributions was assessed using the 
Kolmogorov-Smirnov test.

We then divided eligible patients into groups for further analysis according to the amputation level (transfemoral and transtibial) and the fall history in the previous year (fallers and non-fallers). Fallers were patients reporting at least one fall in the previous year regardless of its severity, and the non-fallers had no reported falls in the same period. Pearson's qui-square and student's $t$-test were used where applicable.

$P$-values $<0.05$ were considered significant with $95 \%$ of confidence interval $\left(\mathrm{Cl}_{95}\right)$. Analysis was performed using IBM $^{\circledR}$ SPSS Statistics version 23 for Windows ${ }^{\circledR}$.

\section{RESULTS}

In Table 1 we present the sample characterization and the differences between transfemoral and transtibial amputees, and between fallers and non-fallers.

From the 138 amputees scheduled for outpatient consultation between October and December 2017, 52 partici- pants met the criteria, completed all assessments and were therefore included in the study and data analysis. From the 86 patients excluded, 42 amputees never attended the consultation and 44 did not meet the criteria. From the 52 study subjects, 42 were men (80.8\%). The mean age was $57.21 \pm 11.55$ years. Concerning the level of amputation, $29(55.8 \%)$ amputees were transtibial and $23(44.2 \%)$ were transfemoral. The most frequent cause of amputation was trauma $(63.5 \%)$, followed by vascular $(25.0 \%)$, and all patients had worn their current prosthetic leg for more than 12 months (range 1 to 5 years). Twenty four amputees (46.1\%) reported using walking aids on a daily basis. Regarding the history of falls, $19(36.5 \%)$ patients recalled at least one fall in the previous year. The number of falls varied from 1 to 11 (mean $1.27 \pm 2.48$ ). Six out of $52(11.5 \%)$ patients had experienced only one fall and $13 / 52(25.0 \%)$ had recurrent falls. Only $6 / 52(11.5 \%)$ patients experienced any fall-related adverse events, all reported as minor injuries according to the $\mathrm{NDNQ}^{\circledR}$ Injury Falls Measure. The $\mathrm{FIM}^{\circledR}$ score, an

Table 1 - Sample characterization and comparison between transfemoral and transtibial amputees and between fallers and non-fallers

\begin{tabular}{|c|c|c|c|c|c|}
\hline & $\begin{array}{c}\text { Transfemoral } \\
(n=23)\end{array}$ & $\begin{array}{c}\text { Transtibial } \\
(n=29)\end{array}$ & $\begin{array}{c}\text { Non-fallers } \\
(n=33)\end{array}$ & $\begin{array}{l}\text { Fallers } \\
(n=19)\end{array}$ & $\begin{array}{c}\text { Total } \\
(n=52)\end{array}$ \\
\hline \multicolumn{6}{|l|}{ Gender [n (\%)] } \\
\hline Female & $5(21.7)$ & $5(17.2)$ & $6(18.2)$ & $4(21.1)$ & $10(19.2)$ \\
\hline Male & $18(78.3)$ & $24(82.8)$ & $27(81.8)$ & $15(78.9)$ & $42(80.8)$ \\
\hline Age/years [mean $\pm \mathrm{SD}]$ & $59.48 \pm 11.56$ & $55.41 \pm 11.41$ & $55.21 \pm 11.91$ & $60.68 \pm 10.27$ & $57.21 \pm 11.55$ \\
\hline $\begin{array}{l}\text { Level of Amputation [n (\%)] } \\
\text { Transtibial } \\
\text { Transfemoral }\end{array}$ & $\mathrm{N} / \mathrm{A}$ & $\mathrm{N} / \mathrm{A}$ & $\begin{array}{l}23(69.7) \\
10(30.3)\end{array}$ & $\begin{array}{c}6(31.6) \\
13(68.4)\end{array}$ & $\begin{array}{l}29(55.8) \\
23(44.2)\end{array}$ \\
\hline $\begin{array}{l}\text { Aetiology of amputation [n (\%)] } \\
\text { Vascular } \\
\text { Traumatic } \\
\text { Tumor } \\
\text { Other }\end{array}$ & $\begin{array}{c}7(30.4) \\
13(56.5) \\
2(8.7) \\
1(4.3)\end{array}$ & $\begin{array}{c}6(20.7) \\
20(69.0) \\
3(10.3) \\
0\end{array}$ & $\begin{array}{c}7(21.2) \\
21(63.3) \\
4(12.1) \\
1(3.0)\end{array}$ & $\begin{array}{c}6(31.6) \\
12(63.2) \\
1(5.3) \\
0\end{array}$ & $\begin{array}{c}13(25.0) \\
33(63.5) \\
5(9.6) \\
1(1.9)\end{array}$ \\
\hline $\begin{array}{l}\text { Walking assistive devices }[\mathrm{n}(\%)]^{\ddagger} \\
\text { Yes } \\
\text { No }\end{array}$ & $\begin{array}{c}17(73.9) \\
6(26.1)\end{array}$ & $\begin{array}{c}7(24.1) \\
22(75.9)\end{array}$ & $\begin{array}{l}14(42.4) \\
19(57.6)\end{array}$ & $\begin{array}{c}10(52.4) \\
9(47.4)\end{array}$ & $\begin{array}{l}24(46.1) \\
28(53.9)\end{array}$ \\
\hline $\begin{array}{l}\text { Any fall in the previous year }[\mathrm{n}(\%)] \\
\text { Yes } \\
\text { No }\end{array}$ & $\begin{array}{l}13(56.5) \\
10(43.5)\end{array}$ & $\begin{array}{c}6(20.7) \\
23(79.3)\end{array}$ & $\mathrm{N} / \mathrm{A}$ & $\mathrm{N} / \mathrm{A}$ & $\begin{array}{l}19(36.5) \\
33(63.5)\end{array}$ \\
\hline $\begin{array}{l}\text { Fall categories [n (\%)] } \\
\text { Non-fallers } \\
\text { Single fallers } \\
\text { Recurrent fallers }\end{array}$ & $\begin{array}{l}10(43.5) \\
4(17.4) \\
9(39.1)\end{array}$ & $\begin{array}{c}23(79.3) \\
2(6.9) \\
4(13.8)\end{array}$ & $\mathrm{N} / \mathrm{A}$ & $\begin{array}{c}\text { N/A } \\
6(31.6) \\
13(68.4)\end{array}$ & $\begin{array}{l}33(63.5) \\
6(11.5) \\
13(25.0)\end{array}$ \\
\hline Number of falls [mean $\pm \mathrm{SD}]^{+}$ & $2.22 \pm 3.23$ & $0.52 \pm 1.30$ & 0 & $1.27 \pm 2.48$ & $1.27 \pm 2.48$ \\
\hline $\begin{array}{l}\text { Fall severity [n (\%)] } \\
\text { Death } \\
\text { Major injury } \\
\text { Moderate injury } \\
\text { Minor injury } \\
\text { None }\end{array}$ & $\begin{array}{c}0 \\
0 \\
0 \\
4(17.4) \\
19(82.6)\end{array}$ & $\begin{array}{c}0 \\
0 \\
0 \\
2(6.9) \\
27(93.1)\end{array}$ & $N / A$ & $\begin{array}{c}0 \\
0 \\
0 \\
6(31.6) \\
13(68.4)\end{array}$ & $\begin{array}{c}0 \\
0 \\
0 \\
6(11.5) \\
46(88.5)\end{array}$ \\
\hline FES score $[$ mean \pm SD] & $81.87 \pm 19.57$ & $86.83 \pm 18.62$ & $82.94 \pm 21.47$ & $87.58 \pm 13.83$ & $84.63 \pm 19.02$ \\
\hline Walking speed/meters per seconds [mean $\pm \mathrm{SD}]^{\ddagger}$ & $0.77 \pm 0.26$ & $1.05 \pm 0.26$ & $0.96 \pm 0.31$ & $0.85 \pm 0.25$ & $0.92 \pm 0.29$ \\
\hline
\end{tabular}

N/A: non-applicable; SD: standard-deviation; FES: Falls Efficacy Scale;

Fall categories: non-fallers: no reported falls in the previous year; single fallers: only one fall reported in the previous year, regardless severity; recurrent fallers: $\geq 2$ falls reported in the previous year, regardless severity.

${ }^{\ddagger}$ Significant difference between transfemoral and transtibial amputees with $p$-value $<0.001$;

+ Significant difference between transfemoral and transtibial amputees with $p$-value 0.025 
inclusion criterion, was $121.06 \pm 5.53$ points.

The transfemoral group used more walking aids $(p<$ 0.001 ) and presented a higher number of falls $[p=0.025$, mean difference $\left.=1.70, \mathrm{Cl}_{95}(0.23 ; 3.17)\right]$ and lower walking speed $\left[p<0.001\right.$, mean difference $=-0.28 \mathrm{~m} / \mathrm{s}, \mathrm{Cl}_{95}(-0.43$; $-0.14)$ ]. No significant differences were found in age and FES scores.

Non-fallers did not differ significantly from fallers, namely in mean age and mean FES score (Table 1).

\section{DISCUSSION}

The amputee outpatient consultation at the department of PRM department has an average of 150 amputees every three months, mainly of geriatric age and of vascular etiology. This study included 52 community-dwelling, middleaged amputees, mostly of traumatic etiology. Therefore, the sample is not representative of amputees treated in our department, since in the $21^{\text {st }}$ century, geriatric age and vascular etiology prevail in all European rehabilitation departments. ${ }^{9,21,28}$

In our study, the prevalence of falls (36.5\%) was found to be lower than that described by other authors, where percentages above $50 \%$ have been reported. . $, 8,9$ Age and functional pattern of the amputees may justify this lower value. Furthermore, the amputees completed a 12-week functional rehabilitation program focusing on kinetic performances and ADL.

Therapeutic programs implemented after amputation are usually effective in reducing the number and severity of falls. ${ }^{19,21,22}$ In this study, fall severity was described in all cases as minor injury. Injurious falls occurred only in $11.5 \%$ of the patients, clearly less than what was previously reported $(26.8 \%$ to $40.4 \%)$ in studies mainly focusing on vascular and geriatric amputees. ${ }^{5,10}$ Wong et al concluded that the higher the number of falls, the greater their severity. ${ }^{10}$ Fall prevention programs and home intervention may limit this risk, particularly in geriatric amputees..$^{29,30}$

In agreement with the literature, ,5,6,31,32 transfemoral amputees presented higher prevalence of falls and lower walking speed, even when using more walking assistive devices. Different impairments in mobility (muscle strength, balance, etc.), energetic demands imposed by the type of prosthesis, and cardiorespiratory performance may justify these findings. Thus, transfemoral amputees are clearly in need of specific interventions, focused on posture control, prosthesis management, aerobic conditioning, and gait training.

Different interventions aim to demonstrate their effectiveness in improving quality and speed of gait. ${ }^{29}$ However, electrotactile and auditory error-based feedback in upperleg prostheses do not have proven efficacy. ${ }^{33}$ Mirror-reflected body image training seems to improve the upright stance control during quiet standing ${ }^{34}$ and vibration technics could partially correct posture asymmetries. ${ }^{35}$ In any case, feedback techniques can contribute to reduce the risk of falling in transfemoral amputees. Smartphone applications for fall detection can also provide real-time warning for gait dis- turbances that suggest a greater risk of falling. ${ }^{30}$ However, there is insufficient evidence that increasing walking speed may reduce the risk of falls in transfemoral amputees.

The self-perception of fear of falling, measured by the FES score, was not significantly different between fallers and non-fallers. Fear of falling, assessed by using a simple yes or no question, was already found not to be related to fall history in a previous study. ${ }^{5}$ As mentioned before, FES intends to identify "low perceived self-efficacy at avoiding falls during essential, non-hazardous activities of daily living". 16,18,25 Therefore, we justify this result with the fact that the amputees included in the study have $\mathrm{FIM}^{\circledR}$ scores equal to or greater than 100 , suggesting high participation capacity based on a reduced fear of falling. Thus, in a community-dwelling amputee population, the FES score does not seem to be useful in clinical practice. Other populations of amputees as well as other fear of falling measures, such as the Activities-Specific Balance Confidence (ABC) scale, ${ }^{12,36}$ should be addressed in the future.

\section{Strengths}

Our study is one of the few Portuguese studies on lower limb amputees published to date,,$^{28}$ and to the best of our knowledge, the very first study comparing transfemoral and transtibial amputees, thus adding an important contribution to better understand the needs of these individuals in our community. We also test the fear of falling using FES, a relatively unexplored instrument for evaluating lower limb amputees. ${ }^{16}$

\section{Limitations}

We only included community-dwelling amputees that reported wearing prosthesis on a daily basis, and who had a $\mathrm{FIM}^{\circledast}$ score equal to or greater than 100 to ensure functionality in such a vulnerable population. This excluded almost as many amputees $(n=44)$ as the ones included $(n=52)$, which means that the scenario depicted in this study does not generalize to patients followed in an amputee outpatient consultation. Second, the cross-sectional study design means there was neither prior assessment nor follow-up of the amputees. The sample size is also limited, thus not allowing for comparison between some of the studied parameters, such as the etiology of the amputation, which may be of clinical interest. Finally, there is also the possibility of under-reporting of falls due to the recall bias of retrospective studies. ${ }^{37}$

\section{CONCLUSION}

This paper contributes information about Portuguese lower limb amputees to the existing body of research. Studies on Portuguese lower limb amputees are scarce and are rarely related to falls. The incidence of falls in communitydwelling lower limb Portuguese amputees with autonomous gait and a $\mathrm{FIM}^{\circledast}$ score equal to or greater than 100 is low and associated with minor injury. However, transfemoral amputee patients have higher fall occurrence, slower walking speed, and increased need for walking aids compared 
to transtibial amputees. There is a low level of interest in using FES to identify fear of falling in this high $\mathrm{FIM}^{\circledR}$ population.

\section{ACKNOWLEDGEMENTS}

The authors would like to thank all the staff of PRM/ CHUC department, namely Paulo Cortez, and to Maria Inês Táboas for reviewing the manuscript.

\section{PROTECTION OF HUMANS AND ANIMALS}

The authors declare that the procedures were followed according to the regulations established by the Clinical Research and Ethics Committee and to the 2013 Helsinki Declaration of the World Medical Association.

\section{REFERENCES}

1. Gallagher P, O'Donovan M, Doyle A, Desmond D. Environmental barriers, activity limitations and participation restrictions experienced by people with major limb amputation. Prosthet Orthot Int. 2015;35:278-84.

2. Burger $\mathrm{H}$. Functioning of persons following lower limb amputation patients' perspective. Med Fluminensis. 2012;48:471-9.

3. Ziegler-Graham K, MacKenzie E, Ephraim P, Travison T, Brookmeyer R. Estimating the prevalence of limb loss in the United States: 2005 to 2050. Arch Phys Med Rehabil. 2008;89:422-9.

4. Ahmad N, Thomas GN, Gill P, Chan C, Torella F. Lower limb amputation in England: prevalence, regional variation and relationship with revascularisation, deprivation and risk factors. A retrospective review of hospital data. J R Soc Med. 2014;107:483-9.

5. Miller WC, Speechley M, Deathe B. The prevalence of risk factors of falling and fear of falling among lower extremity amputees. Arch Phys Med Rehabil. 2001;82:1031-7.

6. Miller WC, Deathe AB, Speechley M, Koval J. The influence of falling, fear of falling, and balance confidence on prosthetic mobility and social activity among individuals with a lower extremity amputation. Arch Phys Med Rehabil. 2001;82:1238-44.

7. Barker W. Assessment and prevention of falls in older people. Nurs Older People. 2014;26:18-24.

8. Kulkarni J, Toole C, Hirons R, Wright S, Morris J. Falls in patients with lower limb amputations: Prevalence and contributing factors. Physiotherapy. 1996;82:130-6.

9. Hunter SW, Batchelor F, Hill KD, Hill AM, Mackintosh S, Payne M. Risk factors for falls in people with a lower limb amputation: a systematic review. PM R. 2016;9:170-80.

10. Wong CK, Chihuri ST, Li G. Risk of fall-related injury in people with lower limb amputations: a prospective cohort study. J Rehabil Med. 2016;48:80-5.

11. Muir S, Berg K, Chesworth B, Klar N, Speechley M. Quantifying the magnitude of risk of balance impairment on falls in community dwelling older adults: a systematic review and meta-analysis. J Clin Epidemiol. 2010;63:389-406.

12. Wong CK, Chen CC, Blackwell WM, Rahal RT, Benoy SA. Balance ability measured with the Berg Balance Scale: a determinant of fall history in community-dwelling adults with leg amputation. J Rehabil Med. 2015;47:80-6.

13. Mancini M, Horak FB. The relevance of clinical balance assessment tools to differentiate balance deficits. Eur J Phys Rehabil Med. 2010;46:23948.

14. Weiss GN, Gorton TA, Read RC, Neal LA. Outcomes of lower extremity amputations. J Am Geriatr Soc. 1990;38:877-83.

15. Collin C, Wade DT, Cochrane GM. Functional outcome of lower limb amputees with peripheral vascular disease. Clin Rehabil. 1992;6:13-21.

16. Barnett C, Vanicek N, Polman R. Temporal adaptations in generic and population specific quality of life and falls efficacy in men with recent lower-limb amputations. J Rehabil Res Dev. 2013;50:437-48.

17. Sions JM, Beisheim EH, Manal TJ, Smith SC, Horne JR, Sarlo FB. Differences in physical performance measures among patients with unilateral lower-limb smputations classified as functional level K3 versus K4. Arch Phys Med Rehabil. 2018;99:1333-41.

18. Melo C. Adaptação cultural e validação da escala "Falls Efficacy Scale" de Tinetti. Rev Assoc Med Bras. 2011;55:192-6.

19. Esquenazi A, DiGiacomo R. Rehabilitation after amputation. J Am

\section{DATA CONFIDENTIALITY}

The authors declare having followed the protocols in use at their working center regarding patients' data publication.

\section{CONFLICTS OF INTEREST}

The authors declare no conflicts of interest.

\section{FUNDING SOURCES}

This research received no specific grant from any funding agency in the public, commercial, or not-for-profit sectors.

Podiatr Med Assoc. 2001;91:13-22.

20. Christensen B, Ellegaard B, Bretler U, Ostrup EL. The effect of prosthetic rehabilitation in lower limb amputees. Prosthet Orthot Int. 1995;19:4652.

21. Gooday $\mathrm{H}$, Hunter J. Preventing falls and stump injuries in lower limb smputees during inpatient rehabilitation: completion of the audit cycle. Clin Rehabil. 2004;18:379-90.

22. Dyer D, Bouman B, Davey M, Ismond K. An intervention program to reduce falls for adult in-patients following major lower limb amputation. Healthc Q. 2008;11:117-21.

23. Guide for the use of the uniform data set for medical rehabilitation, version 4.0. Buffalo: Research Foundation; 1993. p.1-31.

24. Laíns J. Guia para o sistema uniformizado de dados para reabilitação médica (SUDRM). Tradução autorizada pelo Uniform Data Set for Medical Rehabilitation, State University of New York at Buffalo. Coimbra; Repositório Hospitais da Universidade de Coimbra. 1991. [consultado em 2017 jun 01]. Disponível em: http://rihuc.huc.min-saude. pt/handle/10400.4/541.

25. Tinetti ME, Richman D, Powell L. Falls efficacy as a measure of fear of falling. J Gerontol. 1990;45:239-43.

26. Bandura A. Self-efficacy mechanism in human agency. Am Psychol. 1982;37:122-47.

27. Garrard L, Boyle DK, Simon M, Dunton N, Gajewski B. Reliability and validity of the NDNQI ${ }^{\circledR}$ injury falls measure. West $\mathrm{J}$ Nurs Res. 2016;38:111-28.

28. Machado-Vaz I, Roque V, Pimentel S, Rocha A, Duro H. Psychosocial characterization of a Portuguese lower limb amputee population. Acta Med Port. 2012;25:77-82.

29. Highsmith MJ, Andrews CR, Millman C, Fuller A, Kahle JT, Klenow TD, et al. Gait training interventions for lower extremity amputees: a systematic literature review. Technol Innov. 2016;18:99-113.

30. Shawen N, Lonini L, Mummidisetty CK, Shparii I, Albert MV, Kording $\mathrm{K}$, et al. Fall detection in individuals with lower limb amputations using mobile phones: machine learning enhances robustness for real-world applications. JMIR Mhealth Uhealth. 2017;5:e151.

31. Genin JJ, Bastien GJ, Franck B, Detrembleur C, Willems PA. Effect of speed on the energy cost of walking in unilateral traumatic lower limb amputees. Eur J Appl Physiol. 2008;103:655-63.

32. VIlasolli TO, Zafirova B, Orovcanec N, Poposka A, Murtezani A, Krasniqi B. Energy expenditure and walking speed in lower limb amputees: a cross sectional study. Ortop Traumatol Rehabil. 2014;16:419-26.

33. Wentink EC, Talsma-Kerkdijk EJ, Rietman HS, Veltink P. Feasibility of error-based electrotactile and auditive feedback in prosthetic walking. Prosthet Orthot Int. 2015;39:255-59.

34. Hlavackova P, Fristios J, Cuisinier R, Pinsault N, Janura M, Vuillerme N. Effects of mirror feedback on upright stance control in elderly transfemoral amputees. Arch Phys Med Rehabil. 2009;90:1960-3.

35. Duclos C, Roll R, Kavounoudias A, Roll JP, Forget R. Vibration induced post-effects: a means to improve postural asymmetry in lower leg amputees? Gait Posture. 2007;26:595-602

36. Miller WC, Deathe AB, Speechley M. Psychometric properties of the Activities-Specific Balance Confidence Scale among individuals with a lower-limb amputation. Arch Phys Med Rehabil. 2003;84:656-61.

37. Cummings $S$, Nevitt M, Kidd S. Forgetting falls: the limited accuracy of recall of falls in the elderly. J Am Geriatr Soc. 1988;36:613-6. 